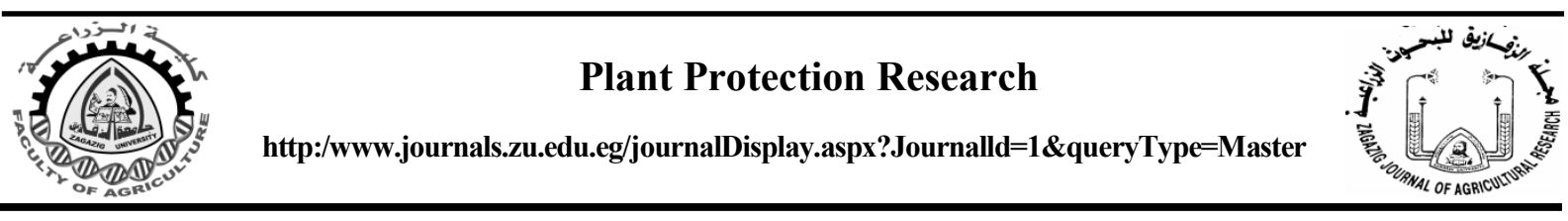

\title{
EFFICACY AND VIRULENCE OF Spodoptera littoralis NUCLEOPOLYHEDROVIRUS on $S$. littoralis LARVAL FEEDING AND SUSCEPTIBILITY
}

\author{
Lamiaa E. Abdel-Khalik", E.A. El-Sheikh, D.A. Ragheb and M-B.A. Ashour \\ Plant Prot. Dept., Fac. Agric., Zagazig Univ., Egypt
}

Received: 06/11/2016 ; Accepted: 04/12/2016

\begin{abstract}
Entomopathogenic baculoviruses have long been recognized as vital environmentally safe alternatives to chemical pesticides. A study for investigating the virulence and susceptibility of Spodoptera littoralis larvae to S. littoralis nucleopolyhedrovirus (SpliNPV) isolate was carried out. Bioassay experiments on the $1^{\text {st }}$ and $2^{\text {nd }}$ larval instars using droplet feeding method revealed that polyhedral for $50 \%$ or $90 \%$ mortality of the $2^{\text {nd }}$ larval instar of $S$. littoralis was significantly lower compared with the $1^{\text {st }}$ instar. While, the $1^{\text {st }}$ instar was killed faster than the $2^{\text {nd }}$ one especially with the higher concentration. The susceptibility of the infected $2^{\text {nd }}$ instar when feeding on different hosts showed that larvae were more susceptible when feeding on eggplant leaves followed by lettuce leaves, artificial diet and tomato leaves as shown by larval weight and reduction in feeding. The reduction in both larval weight and feeding were significantly higher with $1 \times 10^{7} \mathrm{PIB} / \mathrm{ml}$ than $1 \times 10^{4} \mathrm{PIB} / \mathrm{ml}$ in the majority of cases. S. littoralis larvae showed more than 2 times of tolerant to the $3^{\text {rd }}$ passage of SpliNPV on the level of $\mathrm{LC}_{50}$ and more than 18 times tolerant on the level of $\mathrm{LC}_{90}$. The tolerant levels of $S$. littoralis larvae for the $3^{\text {rd }}$ passage of virus was associated with more than $20 \%$ increase in time taken for kill with no changes in DNA patterns regarding subsequent passages in S. littoralis larvae using a restriction enzyme EcoRI.
\end{abstract}

Key words: S. littoralis, SpliNPV, susceptibility, plant hosts, DNA profile.

\section{INTRODUCTION}

Baculoviruses are insect specific entomopathogens belonging to family Baculoviridae. Their occlusion bodies (OBs) contain rod-shaped virions which have circular double stranded DNA. Baculovirus genomes are ranging from 90 to $160 \mathrm{kbp}$ (Blissard and Rohrman, 1990). All baculoviruses composed of the genera nucleopolyhedrovirus (NPV) and granulovirus (GV) (Volkman et al., 1995; Theilmann et al. 2005) that infect lepidopteran species. Jehle et al. (2006) classified baculoviruses into four genera on the basis of hosts. Lepidopteran-specific NPV and GV named Alphabaculovirus and Betabaculovirus, respectively. Hymenopteran-specific NPV named Gammabaculovirus and dipteran-specific baculovirus named Deltabaculovirus. Spodoptera littoralis nucleopolyhedrovirus (SpliNPV) is an

\footnotetext{
${ }^{*}$ Corresponding author: Tel. : +201289925667

E-mail address: elsayed.lamiaa@yahoo.com
}

alphabaculovirus that has been isolated from populations of $S$. littoralis in Egypt, Morocco, France, the Azores islands, Tunisia, and Turkey (Abul Nasr, 1956; Cherry and Summers, 1985; Croizier et al., 1989; Toprak and Gurkan, 2004; Martins et al., 2005; Laarif et al., 2011). Baculoviruses occur naturally and are relatively host-specific. They showed safe to non-target organisms and the mammals (Ashour et al., 2007; Cheng and Lynn, 2009).

The successful application of baculoviruses was initiated from the application of Anticarsia gemmatalis (Hübner) nucleopolyhedrovirus (AgNPV) for controlling A. gemmatalis in soybean (Moscardi, 1999 and 2007). The initial field experiments indicated that AgNPV has a potential as a biopesticide in soybean IPM programs. One reason for AgNPV success in controlling velvetbean caterpillar in Brazil is the collaborative work of researchers and extension 
workers to get farmers familiar and convinced with the benefits of using AgMNPV as a major part in the biological control of the pest in field (Moscardi, 2007 ; Moscardi et al., 2011).

Field and vegetable crops in Egypt are infested by the Egyptian cotton leafworm Spodoptera littoralis (Boisduval) (Lepidoptera: Noctuidae). It is an important and widespread pest not only in Egypt but also in tropical and subtropical regions (Brown and Dewhurst, 1975). According to its many plant hosts, $S$. littoralis named as a polyphgous insect that primarily causes economical yield losses on several crops (Carter, 1984). Examples of economically important crops attacked by $S$. littoralis are cotton, spinach, alfalfa, pepper, eggplant, tomato, lettuce, bean, strawberry, and some ornamental crops throughout the year in Africa, Asia and Europe (Bayoumi et al., 1998; Pineda et al., 2007). Accordingly, more than 40 insecticide formulations belonging to different groups have been registered and used for its control in Egypt (El-Sheikh, 2015a). Because this insect developed high levels of resistance against different groups of conventional insecticides (Smagghe et al., 1999; Aydin and Gürkan, 2006), application of specific programs such as biopesticides would be useful. To focus on the probability of change in the susceptibility, this study aims to test the effects of SpliNPV on reducing growth of $S$. littoralis larvae and accordingly reduce plant feeding damage. Differ in $S$. littoralis susceptibility to SpliNPV was also studied against the first and third viral passes in S. littoralis. For confirming the stability of viral genome during infection cycles, DNA analysis using EcoRI was carried out.

\section{MATERIALS AND METHODS}

\section{Insect and Rearing}

A laboratory colony of the cotton leafworm, S. littoralis, was obtained from Agricultural Research Center (ARC), Dokki, Giza, Egypt. $S$. littoralis larvae were reared on a modified version of artificial diet (Gelernter et al., 1986) in the laboratory at $27 \pm 2^{\circ} \mathrm{C}$ and $65 \pm 5 \% \mathrm{RH}$, with a photoperiod of 16:8 hr., (light:dark). The composition of artificial diet used for preparation was $220 \mathrm{~g}$ white beans, $14 \mathrm{~g}$ agar powder, $4.8 \mathrm{~g}$ ascorbic acid, $0.9 \mathrm{~g}$ sorbic acid, $2.4 \mathrm{~g}$ methyl-p-hydroxybenzoate, $40 \mathrm{~g}$ brewer's yeast, and $700 \mathrm{ml}$ distilled water. Egg masses were obtained by rearing larvae on the diet and allowing emerged adults to feed on $10 \%(\mathrm{~W} / \mathrm{V})$ of honey solution in wide glass jars provided with clean white papers for oviposition. Egg masses were collected daily and transferred into clean plastic containers provided with artificial diet or plant leaves for continuous rearing or experiments.

\section{Virus and Propagation}

An isolate of $S$. littoralis nucleopolyhedrovirus (SpliNPV) from infected S. littoralis larvae was used. Surface contamination method of artificial diet was used for virus propagation in the $3^{\text {rd }}$ and $4^{\text {th }}$ larval instars of $S$. littoralis. The diet was prepared as mentioned above and purified viral particles were spread on the diet surface in a rate of $1 \times 10^{4}$ polyhedral inclusion bodies (PIBs)/ $\mathrm{mm}^{2}$. Thirty $3^{\text {rd }}$ and $4^{\text {th }}$ instar larvae were transferred into each plastic container $(15 \times 10 \times$ $5 \mathrm{~cm}$ ) containing the contaminated diet. Dead larvae were collected and virus was isolated and purified as mentioned in Breitenbach et al. (2013).

\section{Droplet Feeding Bioassay}

Droplet feeding method (Hughes et al., 1986) was used for testing the virulence of SpliNPV on both $1^{\text {st }}$ and $2^{\text {nd }}$ larval instars of S. littoralis. Five concentrations of SpliNPV ranging from $1 \times 10^{4}$ to $1 \times 10^{8} \mathrm{PIBs} / \mathrm{ml}$ were prepared by mixing viral suspension with $10 \%$ sucrose and $5 \%$ blue food dye (El-Sheikh et al., 2011) to give the required concentrations. New $1^{\text {st }}$ and $2^{\text {nd }}$ instar larvae (within $12 \mathrm{hr}$.) of $S$. littoralis were exposed to concentrations of SpliNPV in the form of droplets for $\sim 10 \mathrm{~min}$. Thirty larvae showed drinking from virus concentrations were individually transferred for each concentration into $1 \mathrm{OZ}$ cups (Frontier Agricultural Services, Newark, DE) supplied with fresh clean diet and kept on the above mentioned conditions. Treatments were observed daily and the number of dead larvae was recorded for 10 days post infection (d.p.i.). Larvae dead in the initial 24 $\mathrm{hr}$., were excluded from final larval mortality and considered injured during transfer. Control 
experiments were done by exposing larvae $\left(1^{\text {st }}\right.$ or $2^{\text {nd }}$ ) to droplets without virus. All treatment or control experiments were repeated three times.

\section{Surface Contamination Bioassay}

The propagated and purified virus in $S$. littoralis larvae at the beginning of experiments was considered the $1^{\text {st }}$ passage. The $1^{\text {st }}$ passed polyhedra was used for second infection of larvae to get the purified particles of the $2^{\text {nd }}$ passage. The $2^{\text {nd }}$ passed polyhedra was used for third infection of larvae to get the purified particles of the $3^{\text {rd }}$ passage. The $1^{\text {st }}$ and $3^{\text {rd }}$ viral passes of SpliNPV were used in surface contamination bioassay on the $2^{\text {nd }}$ larval instar. Six concentrations ranging from 1.6 to 5000 $\mathrm{PIB} / \mathrm{mm}^{2}$ were prepared in $\mathrm{dH}_{2} \mathrm{O}$ and used. Concentrations were spread on the surface of artificial diet prepared in plastic containers $(15 \times$ $10 \times 5 \mathrm{~cm}$ ). Containers were left for $15 \mathrm{~min}$ at room temperature for air dry. Thirty larvae of the $2^{\text {nd }}$ instar larvae were transferred into each contaminated diet. Larvae were allowed to feed on the contaminated diet for $24 \mathrm{hr}$., before transferring individually into clean diet in $1 \mathrm{OZ}$ cups. Times of transferring larvae on clean diet were considered as time zero for calculating mortality percentage. Larval mortality was recorded daily for 10 d.p.i. on the previous conditions. Control was used for comparison and done by feeding larvae on clean diet only. Experiments of the treatments and control were repeated three times as reported in El-Sheikh (2006).

\section{Time-Mortality Response Determination}

Time required for $50 \%\left(\mathrm{LT}_{50}\right)$ or $90 \%\left(\mathrm{LT}_{90}\right)$ mortality was calculated for droplet feeding experiments on the $1^{\text {st }}$ and $2^{\text {nd }}$ instar larvae of $S$. littoralis using concentrations of $1 \times 10^{6}$ and $1 \times 10^{8} \mathrm{PIB} / \mathrm{ml}$. For surface contamination experiments on the $2^{\text {nd }}$ instar, $\mathrm{LT}_{50}$ was calculated using concentrations of 200 and 5000 $\mathrm{PIB} / \mathrm{mm}^{2}$. The same procedures mentioned above were used except that mortality was recorded $12 \mathrm{hr}$., intervals. All experiments were repeated three times.

\section{Effect of Infection on Larval Weight and Feeding Damage}

The effect of SpliNPV on larval weight and feeding damage was examined by infecting the $2^{\text {nd }}$ larval instar of $S$. littoralis using two concentrations of $1 \times 10^{4}$ and $1 \times 10^{7} \mathrm{PIB} / \mathrm{ml}$ through droplet feeding method. Preparation of virus concentrations and infection were done as mentioned above. After infection, 30 larvae were individually transferred into $1 \mathrm{OZ}$ cups containing enough amounts of diet, tomato leaves, lettuce leaves or eggplant leaves for each concentration. Larval weight was recorded in the beginning of experiments (day 0 ) and at days 3 , 6 and 9 post infection (p.i.). Diet and plant leaves were replaced each day with fresh ones and their weights were recoded before feeding and after $24 \mathrm{hr}$., of feeding. Decrease in weight of diet or plant leaves due to feeding of infected or un-infected control larvae were recorded at days 1, 4, 7 and 10. A piece of diet or plant leaves were used as control without any feed for subtracting the percentage of normal decrease from those recorded due to larval feeding.

\section{DNA Extraction and Analysis}

Infected larvae from the $1^{\text {st }}$ and $3^{\text {rd }}$ passages were collected separately in $50 \mathrm{ml}$ conical tubes. Occlusion bodies (OBs) were released from infected larvae, suspended in $30 \mathrm{ml}$ of PBS, and filtered twice through cheesecloth. OBs were incubated in $15 \mathrm{ml}$ of $0.1 \mathrm{M}$ sodium bicarbonate for $30 \mathrm{~min}$ at $37^{\circ} \mathrm{C}$ for releasing virions. DNA was obtained from virus particles by incubating virions overnight at $37^{\circ} \mathrm{C}$ in the presence of proteinase $\mathrm{K}(200 \mu \mathrm{g} / \mathrm{ml})$. Viral DNA was subsequently phenol:chloroform extracted and re-suspended in $\mathrm{dH}_{2} \mathrm{O}$ as described in Breitenbach et al. (2013). For analyses, DNA was digested for $1 \mathrm{hr}$., at $37^{\circ} \mathrm{C}$ with a restriction enzyme EcoRI (Invitrogen Corp., CA, USA). Digested DNA was electrophoresed on $1 \%$ agarose gel and stained with ethidium bromide solution according to standard techniques of Sambrook et al. (1989).

\section{Statistical Analysis}

Probit analysis program version 3.1 (Finney, 1971) was used to calculate lethal concentrations (LCs) and their corresponding 95\% confidence limits (CLs). ViStat 2.1 program (Hughes, 1990) was used for calculating the lethal time (LT) values. Values of $\mathrm{LC}_{50}$ and $\mathrm{LC}_{90}$ were considered significantly different when their respective CLs did not overlap. Larval and leaf/diet weights were analyzed using SPSS 14 for Windows by least significant difference (LSD) of one-way ANOVA. 


\section{RESULTS AND DISCUSSION}

Susceptibility of the $1^{\text {st }}$ and $2^{\text {nd }}$ larval instars of $S$. littoralis to SpliNPV was tested using different concentrations by droplet feeding method (Tables 1 and 2). Data presented in Table 1 show lethal concentrations of 50 and $90 \%$ of SpliNPV against $1^{\text {st }}$ and $2^{\text {nd }}$ instars of $S$. littoralis which indicate that number of polyhedra used to kill $50 \%$ or $90 \%$ of the $2^{\text {nd }}$ instar is less than that used to kill the same percentage of the $1^{\text {st }}$ instar (Table 1). This difference may be attributed to the difference in consumed amounts of viral solution by each instar that is higher with older instar larvae compared with early instar larvae. The high amounts consumed by the $2^{\text {nd }}$ instar compared with the $1^{\text {st }}$ instar might reflect high numbers of viral polyhedra consumed and causing high mortality.

To show the effect of viral concentration in reducing time taken for killing $S$. littoralis larvae, two concentrations of $1 \times 10^{6}$ and $1 \times 10^{8}$ $\mathrm{PIB} / \mathrm{ml}$ were used (Table 2). When $1 \times 10^{6}$ $\mathrm{PIB} / \mathrm{ml}$ was tested, the time taken for killing 50 and $90 \%$ of the $1^{\text {st }}$ larval instar was longer than that of the $2^{\text {nd }}$ instar, while it was opposite when $1 \times 10^{8} \mathrm{PIB} / \mathrm{ml}$ was the infection concentration through droplet feeding method. Percentage of decreasing time by increasing concentration was higher in the $1^{\text {st }}$ instar comparing with the $2^{\text {nd }}$ instar larvae (Table 2).

Several characteristics should exist in baculoviruses to make them ideal candidates as pest control agents. Efficacy and biosafety are major parameters in their use. Wild type and genetically modified baculoviruses tested on non-target organisms showed no direct effects on beneficial insects and rats (McNitt et al., 1995; Ashour et al., 2007). Also, they showed high virulent effects on lepidopteran insects (ElSheikh et al., 2011; El-Sheikh, 2014). Efficacy of SpliNPV was studied on S. littoralis under field (Topper et al., 1984; Jones et al., 1994) and laboratory (Grzywacz et al., 1998; Ashour et al., 2007) conditions as well as other spodopteran species (El-Sheikh, 2015b). This virus showed successful control of $S$. littoralis in the field as reported by Topper et al. (1984) and showed high effectiveness against other species of $S$. frugiperda and S. exigua (El-Sheikh, 2015b) in a rate similar to what reported in the current study. Time taken for mortality was higher in late instars compared with early instars especially with higher concentrations as showed in the current study. In agreement, Abbas and Young (1991) found that $\mathrm{LT}_{50}$ values were higher in late instars of the soybean looper, Pseudoplus includes than in early instars.

The effect of infection on the weight of the $2^{\text {nd }}$ instar larvae was investigated using different feeding hosts to show the effect of host on larval growth of infected larvae compared with control (Fig. 1). Also, it was showed that larval growth was depending on the type of the host. Control larvae of $S$. littoralis showed the highest increase in weight when fed on artificial diet followed by feeding on lettuce, tomato and eggplant leaves. Larval weight of infected larvae, with $1 \times 10^{4}$ and $1 \times 10^{7} \mathrm{PIB} / \mathrm{ml}$, was affected started from day three when fed on diet, lettuce or eggplant leaves. Significant decrease in weight of larvae fed continuously for 9 days p.i on diet, tomato and lettuce leaves compared with control. All larvae infected with both concentrations and fed on eggplant leaves dead before day 6 p.i. probably because eggplant is un-favorite host for $S$. littoralis comparing with other plant hosts tested in this study. Larvae infected with $1 \times 10^{7} \mathrm{PIB} / \mathrm{ml}$ showed significant decrease in weight compared with $1 \times 10^{4} \mathrm{PIB} / \mathrm{ml}$ and control in different time points in all hosts except with tomato leaves (Fig. 1).

Significant reduction in leaf weight started in the $1^{\text {st }}$ day with non-infected control larvae especially with lettuce and eggplant. Higher concentration of $1 \times 10^{7} \mathrm{PIB} / \mathrm{ml}$ was more effective in reducing leaves and artificial diet weight. The lower concentration of $1 \times 10^{4} \mathrm{PIB} /$ $\mathrm{ml}$ was effective in reducing leaves damage before day 10 as it showed significant reduction in diet/leaf weights as much as in control experiments (Fig. 2).

The reduction in larval weight and growth is a critical parameter for minimizing plant damage by insect hosts. In this study, higher concentration of SpliNPV was effective in reducing $S$. littoralis larval weight and subsequently reduced larval feeding damage comparing with the lower viral concentration and un-infected control larvae. 
Table 1. Lethal concentrations of Spodoptera littorais nucleopolyhedrovirus (SpliNPV) on the $1^{\text {st }}$ and $2^{\text {nd }}$ instars of $S$. littoralis after exposure into virus concentrations by droplet feeding method

\begin{tabular}{cccccc}
\hline Instar $^{*}$ & No. $^{* *}$ & \multicolumn{2}{c}{ Lethal concentrations (PIB/ml) (95\% CL) } & Slope \pm SE & $\boldsymbol{X}^{\mathbf{2}^{* * * *}}$ \\
\cline { 3 - 4 } & & $\mathbf{L C}_{\mathbf{5 0}}$ & $\mathbf{L C} \mathbf{C}_{\mathbf{9 0}}$ & & \\
\hline \multirow{2}{*}{$1^{\text {st }}$} & 120 & $\begin{array}{c}2.5 \times 10^{5 \mathbf{A}} \\
\left(1.3 \times 10^{5}-4.5 \times 10^{5}\right)\end{array}$ & $\begin{array}{c}1.2 \times 10^{8 \mathbf{A}} \\
\left(4.5 \times 10^{7}-4.9 \times 10^{8}\right)\end{array}$ & $0.5 \pm 0.04$ & 5.3 \\
& & $1.4 \times 10^{5 \mathbf{B}}$ & $1.2 \times 10^{7 \mathbf{B}}$ & & \\
$2^{\text {nd }}$ & 120 & $\left(8.7 \times 10^{4}-2.3 \times 10^{5}\right)$ & $\left(6.2 \times 10^{6}-2.8 \times 10^{7}\right)$ & $0.6 \pm 0.05$ & 4.8 \\
& & & & \\
\hline
\end{tabular}

- Values of lethal concentrations $\left(\mathrm{LC}_{50}\right.$ or $\mathrm{LC}_{90}$ ) between $1^{\text {st }}$ and $2^{\text {nd }}$ instars are considered significantly different when their confidence limits (CL) did not overlap and showed with different uppercase letters.

${ }^{*}$ New emergence $1^{\text {st }}$ and $2^{\text {nd }}$ instars were used in experiments which repeated 3 times.

${ }^{* *}$ No. is the total number of larvae used for each experiment.

${ }^{* * *} X^{2}$ means chi-square heterogeneity.

Table 2. Lethal-time (LT) of the $1^{\text {st }}$ and $2^{\text {nd }}$ instars of Spodptera littoralis due to feeding on $S$. littorais nucleopolyhedrovirus (SpliNPV) droplets containing viral particles at concentrations of $1 \times 10^{6}$ or $1 \times 10^{8} \mathrm{PIB} / \mathrm{ml}$

\begin{tabular}{|c|c|c|c|c|c|c|c|}
\hline \multirow[t]{3}{*}{ Instar $^{*}$} & \multirow[t]{3}{*}{ No. ${ }^{* * *}$} & \multicolumn{4}{|c|}{ Lethal times (hr.) } & \multirow{2}{*}{\multicolumn{2}{|c|}{$\begin{array}{c}\text { Decrease in time } \\
(\%)\end{array}$}} \\
\hline & & \multicolumn{2}{|c|}{$1 \times 10^{6} \mathrm{PIB} / \mathrm{ml}$} & \multicolumn{2}{|c|}{$1 \times 10^{8} \mathrm{PIB} / \mathrm{ml}$} & & \\
\hline & & $\mathbf{L T}_{\mathbf{5 0}}$ & $\mathbf{L T}_{\mathbf{9 0}}$ & $\mathbf{L T}_{\mathbf{5 0}}$ & $\mathbf{L T}_{\mathbf{9 0}}$ & $\mathbf{L T}_{50}$ & $\mathbf{L T}_{\mathbf{9 0}}$ \\
\hline $1^{\mathrm{st}}$ & 120 & 168.0 & 357.6 & 55.2 & 132.0 & 67.1 & 63.1 \\
\hline $2^{\text {nd }}$ & 120 & 151.2 & 328.8 & 84.0 & 141.6 & 44.4 & 56.9 \\
\hline
\end{tabular}

${ }^{*}$ New emergence $1^{\text {st }}$ and $2^{\text {nd }}$ instars were used in experiments which repeated 3 times.

${ }^{* *}$ No. is the total number of larvae used for each experiment. 


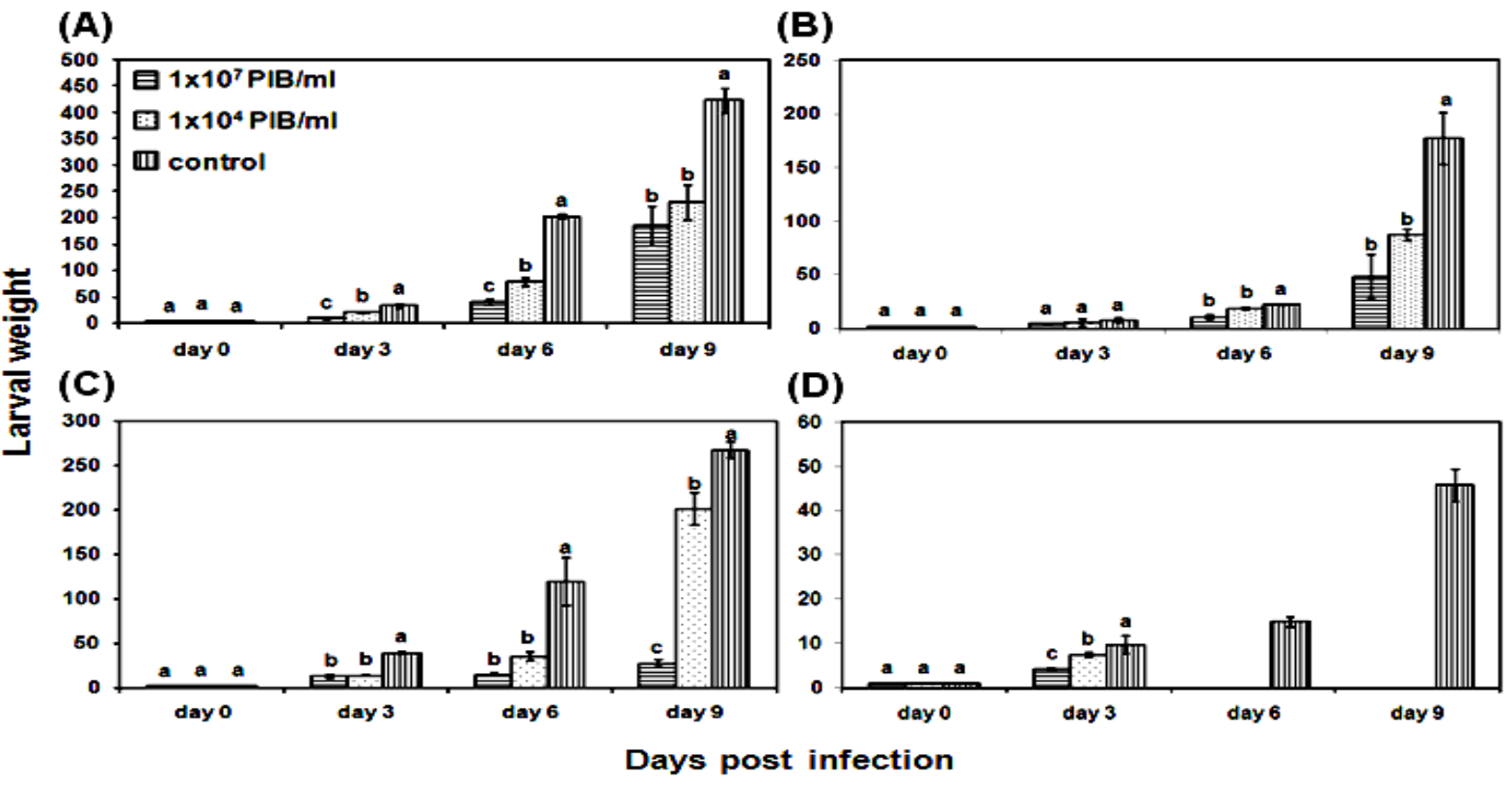

Fig. 1. Increase in individual larval weight of the $2^{\text {nd }}$ instar of Spodoptera littoralis after infection with $1 \times 10^{4}$ or $1 \times 10^{7} \mathrm{PIB} / \mathrm{ml}$ then transferred on artificial diet (A), tomato leaves (B), lettuce leaves $(C)$, or eggplant leaves (D) for 10 days. Mean weight of alive larvae was recorded immediately before infection (day 0 ) and after 3, 6, and 9 days of infection. Differences between treatments and control were analyzed by SPSS 14 using LSD of oneway ANOVA for each time point. Bars holding different letters are statistically different at $\mathbf{P}<\mathbf{0 . 0 5}$

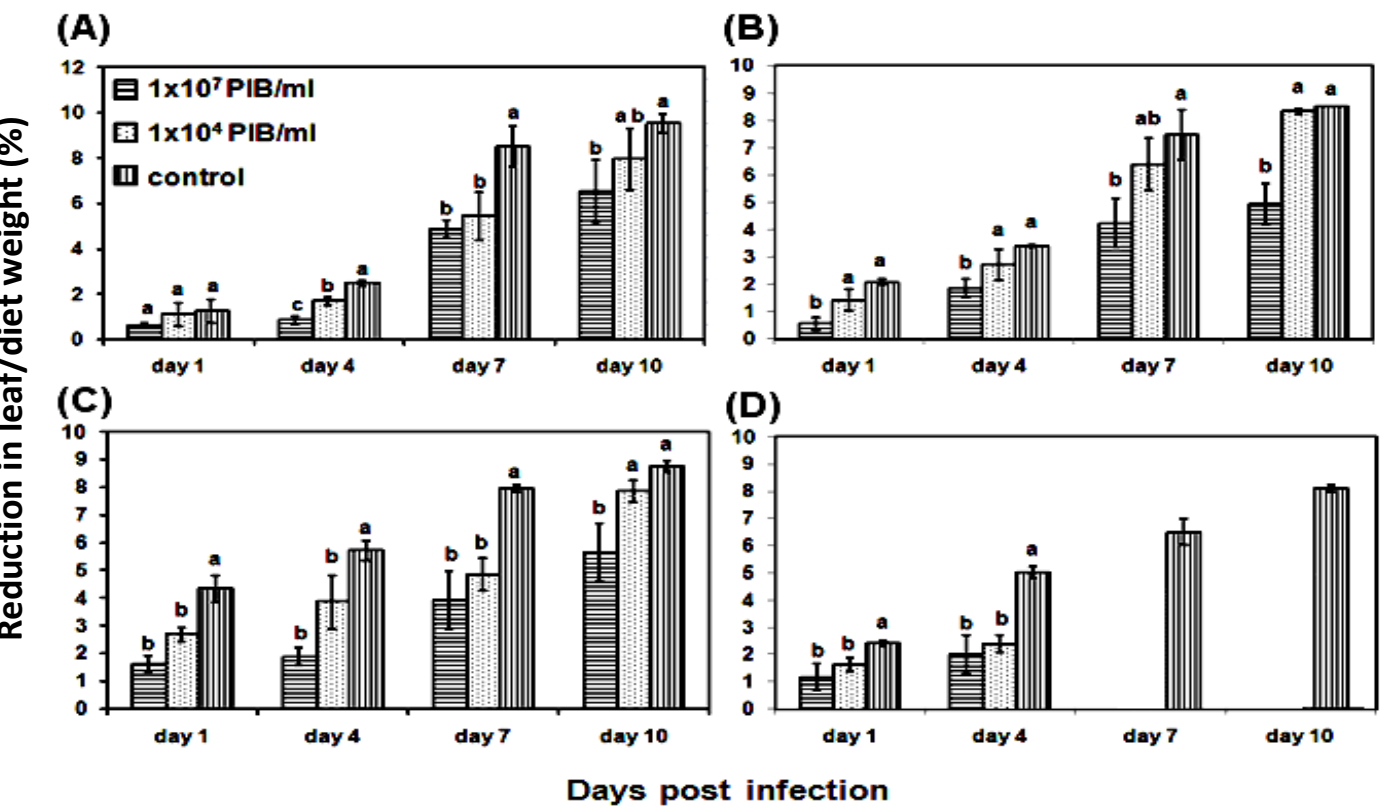

Fig. 2. Mean percentage of reduction in artificial diet (A), tomato leaves (B), lettuce leaves (C), and eggplant leaves (D) due to feeding of Spodoptera littoralis $2^{\text {nd }}$ instar larvae for 10 days after exposure to droplets containing $1 \times 10^{4}$ or $1 \times 10^{7} \mathrm{PIB}$ of SpliNPV/ml (treated) or free virus droplets (control). Differences between treatments and control were analyzed by SPSS 14 using LSD of one-way ANOVA for each time point. Bars holding different letters are statistically different at $\mathbf{P}<\mathbf{0 . 0 5}$ 
The effects of continuous exposure of $S$. littoralis larvae to SpliNPV on the susceptibility of the $2^{\text {nd }}$ instar of $S$. littoralis to different virus passages are presented in Tables 3 and 4 . First and $3^{\text {rd }}$ passages were examined on the $2^{\text {nd }}$ larval instar of $S$. littoralis to show the virulent effect of the virus (Table 3 ) and time for $50 \%$ mortality (Table 4). Obtained data showed that concentrations of the tested virus caused $50 \%$ and $90 \%$ mortality of the $1^{\text {st }}$ passage are $0.5 \times 10^{2} \mathrm{PIB} / \mathrm{mm}^{2}$ and $1.7 \times 10^{4} \mathrm{PIB} / \mathrm{mm}^{2}$, respectively. While, mortality data of the $3^{\text {rd }}$ passage of SpliNPV showed that concentrations caused $50 \%$ and $90 \%$ mortality increased comparing with $1^{\text {st }}$ viral pass and recorded $1.4 \times 10^{2}$ and $3.2 \times 10^{5} \mathrm{PIB} / \mathrm{mm}^{2}$, respectively. Increase in the number of viral polyhedra used to kill $50 \%$ and $90 \%$ of $S$. littoralis larvae in the $3^{\text {rd }}$ passage comparing to $1^{\text {st }}$ passage are 2.8 and 18.8 times, respectively (Table 3 ).

When the $2^{\text {nd }}$ instar larvae of $S$. littoralis was exposed to the concentration of $200 \mathrm{PIB} / \mathrm{mm}^{2}$, time to kill 50\% was increased from $206.4 \mathrm{hr}$., in the $1^{\text {st }}$ viral pass to $254.4 \mathrm{hr}$, , in the $3^{\text {rd }}$ viral pass with $23.3 \%$ increase. While, time increased by $30 \%$ in the $3^{\text {rd }}$ passage comparing with the $1^{\text {st }}$ passage when larvae exposed to $5000 \mathrm{PIB} / \mathrm{mm}^{2}$. Times to kill $50 \%$ were decreased by increasing concentration which recorded 206.4 and $120 \mathrm{hr}$, in the $1^{\text {st }}$ viral pass for 200 and $5000 \mathrm{PIB} / \mathrm{mm}^{2}$, respectively with $14.9 \%$ decrease in time. Although that isolate of the $3^{\text {rd }}$ viral pass takes more time for killing 50\%, using high concentrations $\left(5000 \mathrm{PIB} / \mathrm{mm}^{2}\right)$ decreases time taken for $50 \%$ mortality by $38.7 \%$ comparing to $14.9 \%$ in the $1^{\text {st }}$ pass (Table 4 ).

Continuous exposure of $S$. littoralis larvae to a strain of SpliNPV has resulted in low mortality as indicated by higher number of polyhedra required for killing 50 or $90 \%$ in the $3^{\text {rd }}$ passage comparing to the $1^{\text {st }}$ passage. Also, time for $50 \%$ mortality increased by increasing number of virus passages inside $S$. littoralis larvae. The decrease in larval susceptibility due to continuous exposure to NPV was reported in $S$. frugiperda as indicated in the $1^{\text {st }}$ larval instar that showed high levels of tolerance to a selected $S$. frugiperda nucleopolyhedrovirus (SfNPV) strain comparing to a wild type strain (Fuxa and Richter, 1992). In an experiment for measuring relative susceptibilities to NPV, Briese et al. (1980) showed that a strain of lightbrown apple moth, Epiphyas postvittana, exposed several times to NPV are more than 50 times resistant to NPV than a laboratory strain and even more than 100 times resistant compared with a field strain.

Analysis of SpliNPV genome using a restriction endonuclease EcoRI for the $1^{\text {st }}$ and $3^{\text {rd }}$ passages (Fig. 3) revealed no differences in the patterns of DNA fragments. The similarity in DNA patterns indicates that SpliNPV genome did not change during subsequent infection of the insect host in the laboratory, which its stability previously reported in the semi field experiments (Ashour et al., 2007).

Table 3. Susceptibility of the $2^{\text {nd }}$ instar larvae of Spodoptera littoralis when exposed to subsequent passes/ replications of $S$. littoralis nucleopolyhedrovirus (SpliNPV)

\begin{tabular}{|c|c|c|c|c|c|}
\hline \multirow[t]{2}{*}{ Replications/passes" } & \multirow[t]{2}{*}{ No." } & \multicolumn{2}{|c|}{ Lethal concentrations $\left(\mathrm{PIB} / \mathrm{mm}^{2}\right)(95 \% \mathrm{CL})$} & \multirow[t]{2}{*}{ Slope \pm SE } & \multirow[t]{2}{*}{$X^{2^{2 * 27}}$} \\
\hline & & $\mathbf{L C}_{50}$ & $\mathbf{L C}_{90}$ & & \\
\hline $1^{\text {st }}$ replication/pass & 40 & $\begin{array}{c}0.5 \times 10^{2 \mathrm{~A}} \\
\left(0.07 \times 10^{2}-3 \times 10^{2}\right)\end{array}$ & $\begin{array}{c}1.7 \times 10^{4 \mathrm{~A}} \\
\left(1.6 \times 10^{4}-2.6 \times 10^{6}\right)\end{array}$ & $0.5 \pm 0.1$ & 1.2 \\
\hline $3^{\text {rd }}$ replication $/$ pass & 60 & $\begin{array}{c}1.4 \times 10^{2 \mathrm{~A}} \\
\left(0.7 \times 10^{2}-3 \times 10^{2}\right)\end{array}$ & $\begin{array}{c}3.2 \times 10^{5 \mathrm{~A}} \\
\left(4.9 \times 10^{4}-7.6 \times 10^{6}\right)\end{array}$ & $0.8 \pm 0.1$ & 6.9 \\
\hline DT (times) ${ }^{* * * *}$ & & 2.8 & 18.8 & & \\
\hline
\end{tabular}

\footnotetext{
- Values of lethal concentrations $\left(\mathrm{LC}_{50}\right.$ or $\left.\mathrm{LC}_{90}\right)$ between $1^{\text {st }}$ and $2^{\text {nd }}$ instars are considered significantly different when their confidence limits (CL) did not overlap and showed with different uppercase letters.

* $1^{\text {st }}$ pass obtained from infected larvae with SpliNPV, and then the $1^{\text {st }}$ pass was used for insect infection and obtaining the $2^{\text {nd }}$ pass. While, the $3^{\text {rd }}$ pass obtained from infected larvae with the $2^{\text {nd }}$ pass.

${ }^{* *}$ No. is the total number of larvae used for each experiment.

${ }^{* * *} X^{2}$ means chi-square heterogeneity.

${ }^{* * * *} \mathrm{DT}=$ degree of tolerant which calculated by dividing $\mathrm{LC}_{50}$ or $\mathrm{LC}_{90}$ of the $3^{\text {rd }}$ pass $/ \mathrm{LC}_{50}$ or $\mathrm{LC}_{90}$ of the $1^{\text {st }}$ pass.
} 
Table 4. The effect of increase in Spodoptera littoralis nucleopolyhedrovirus (SpliNPV) polyhedra and increase in viral passes on the time taken for $\mathbf{5 0 \%}$ mortality $\left(\mathbf{L T}_{50}\right)$ in the $2^{\text {nd }}$ larval instar of $S$. littoralis

\begin{tabular}{|c|c|c|c|c|}
\hline \multirow[t]{2}{*}{ Replications/Passes" } & \multirow[t]{2}{*}{ No. $^{* * *}$} & \multicolumn{2}{|c|}{ Median lethal time (hr.) } & \multirow{2}{*}{$\begin{array}{c}\text { Decrease in } \\
\text { time } \\
(\%)\end{array}$} \\
\hline & & $200\left(\mathrm{PIB} / \mathrm{mm}^{2}\right)$ & $5000\left(\mathrm{PIB} / \mathrm{mm}^{2}\right)$ & \\
\hline $1^{\text {st }}$ replication/pass & 120 & 206.4 & 120.0 & 14.9 \\
\hline $3^{\text {rd }}$ replication/pass & 120 & 254.4 & 156.0 & 38.7 \\
\hline Increase in time (hr.) ${ }^{* * *}$ & & 1.23 & 1.3 & \\
\hline Increase in time (\%) & & 23.3 & 30 & \\
\hline
\end{tabular}

${ }^{7} 1^{\text {st }}$ pass obtained from infected larvae with SpliNPV, and then the $1^{\text {st }}$ pass was used for insect infection and obtaining the $2^{\text {nd }}$ pass. While, the $3^{\text {rd }}$ pass obtained from infected larvae with the $2^{\text {nd }}$ pass.

${ }^{* *}$ No. is the total number of larvae used for each experiment.

${ }^{* * *}$ Increase in time was calculated by subtracting $\mathrm{LT}_{50}$ value of the $1^{\text {st }}$ pass from $3^{\text {rd }}$ pass for 200 or 5000 $\mathrm{PIB} / \mathrm{mm}^{2}$.

${ }^{* * * *}(\%)$ decrease in time was calculated between viral concentrations used for $1^{\text {st }}$ or $3^{\text {rd }}$ pass by $\left[\left(\mathrm{LT}_{50}\right.\right.$ value of $200 \mathrm{PIB} \mathrm{ml}{ }^{-1}-\mathrm{LT}_{50}$ value of $\left.5000 \mathrm{PIB} \mathrm{ml}{ }^{-1}\right) \times 100 / \mathrm{LT}_{50}$ value of $\left.200 \mathrm{PIB} \mathrm{ml}{ }^{-1}\right]$.

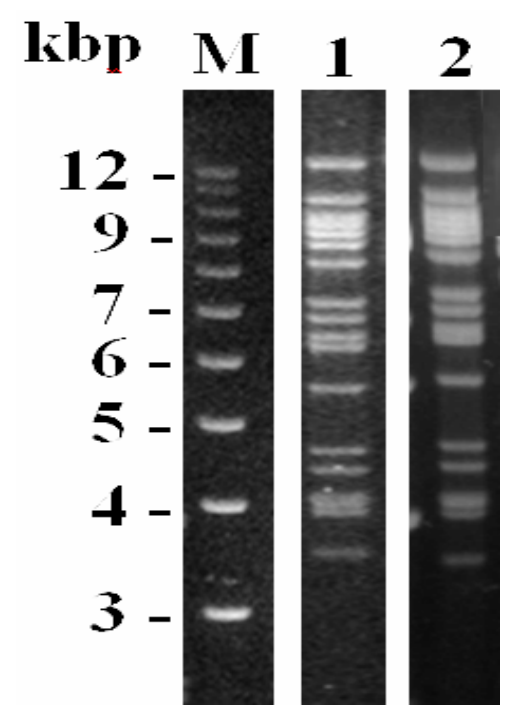

Fig. 3. Spodoptera littoralis nucleopolyhedrovirus genome for $1^{\text {st }}$ pass (lane 1$)$ and $3^{\text {rd }}$ pass (lane 2) cut with $E c o R I$ restriction enzyme and run on $1 \%$ Agarose gel. Lane $M$ represents the $1 \mathrm{kbp}$ plus DNA ladder with standard fragments visable in this figure from 3000 bp to 12000 bp 
In conclusion, SpliNPV is a valuable biopesticide against the Egyptian cotton leaf worm. It is effective against early instars in killing and reducing both larval weight and feeding damage when a reasonable concentration is used. In the opposite way, continuous exposure of $S$. littoralis larvae to virus particles might change insect susceptibility toward resistance in a very few generations. This phenomenon requires using SpliNPV within integrated pest management programs.

\section{REFERENCES}

Abbas, A. and S.Y. Young (1991). Influence of larval age and temperature on effectiveness of a nuclear polyhedrosis virus in the soybean looper, Pseudoplus includens (Lepidoptera: Noctuidae) on soybean. Biol. Cont., 1: 334338.

Abul Nasr, S. (1956). Polyhedrosis virus disease on cotton leafworm Prodenia litura F. Bulletien of the Entomol. Soc. Egypt, 40: 321-332.

Ashour, M.B., D.A. Ragheb, E.A. El-Sheikh, E.A. Gomaa, S.G. Kamita and B.D. Hammock (2007). Biosafety of recombinant and wild type nucleopolyhedroviruses as bioinsecticides. Int. J. Environ. Res. Publ. Health, 4 (2): 111-125.

Aydin, M.H. and M.O. Gürkan (2006). The efficacy of spinosad on different strains of Spodoptera littoralis (Boisduval) (Lepidoptera: Noctuidae). Turk. J. Biol., 30 : 5-9.

Bayoumi, A.E., R. Balana-Fouce, A.K. Sobeiha and E.M.K. Hussein (1998). The biological activity of some chitin synthesis inhibitors against the cotton leafworm Spodoptera littoralis (Boisduval), (Lepidoptera: Noctuidae). Bol. Sanid. Vegetal. Plagas., 24: 499-506.

Blissard, G.W. and G.F. Rohrman (1990). Baculovirus diversity and molecular biology. Annu. Rev. Entomol., 35: 127-155.

Breitenbach, J.E., E.A. El-Sheikh, R.L. Harrison, D.L. Rowley, M.E. Sparks, D.E. Gundersenrindal and H.J. Popham (2013). Determination and analysis of the genome sequence of Spodoptera littoralis multiple nucleopolyhedrovirus. Virus Res., 171: 194208.
Briese, D.T., H.A. Mende, T.D.C. Grace and P.W. Geier (1980). Resistance to a nuclear polyhedrosis virus in the light-brown apple moth Epiphyas postvittana (Lepidoptera: Tortricidae). J. Invert. Pathol., 36: 21 1-215.

Brown, E.S. and C.F. Dewhurst (1975). The genus Spodoptera in Africa and the near east. Bull. Entomol. Res., 65: 221-262.

Carter, D. (1984). Pest Lepidoptera of Europe with Special Reference to the British Isles. Junk Publishers, Dordrecht, The Netherlands.

Cheng, X.W. and D.E. Lynn (2009). Baculovirus interactions in vitro and in vivo. Adv. Appl. Microbiol., 68 : 217-239.

Cherry, C.L. and M.D. Summers (1985). Genotypic variation among wild isolates of two nuclear polyhedrosis viruses isolated from Spodoptera littoralis. J. Invert. Pathol., $46: 289-295$.

Croizier, G., K. Boukhoudmi-Amiri and L. Croizier (1989). A physical map of Spodoptera littoralis B-type nuclear polyhedrosis virus genome. Arch. Virol., 104: 145-151.

El-Sheikh, E.A. (2006). Biosafety of a pest control biotechnology agent. Ph.D. Thesis, Zagazig Univ., 167.

El-Sheikh, E.A. (2014). Virulence and pathogenicity of recombinant nucleopolyhedroviruses expressing a scorpion toxin and an insect enzyme on Agrotis ipsilon (Lepidoptera: Noctuidae) larvae. Afr. Entomol., 22 (3): 512-518.

El-Sheikh, E.A. (2015a). Comparative toxicity and sublethal effects of emamectin benzoate, lufenuron and spinosad on Spodoptera littoralis Boisd. (Lepidoptera: Noctuidae). Crop Prot., 67: 228-234.

El-Sheikh, E.A. (2015b). Efficacy of Spodoptera littoralis nucleopolyherdovirus on Spodoptera frugiperda (J.E. Smith) and Spodoptera exigua (Hübner): virulence, biological effects, and inhibition of juvenile hormone esterase. Egypt. J. Biol. Pest. Cont., 25 (3): 587-595.

El-Sheikh, E.A., S.G. Kamita, K. Vu and B.D. Hammock (2011). Improved insecticidal 
efficacy of a recombinant baculovirus expressing stabilized $\mathrm{JH}$ esterase from Manduca sexta. Biol. Cont., 58: 354-361.

Finney, D.J. (1971). Probit Analysis. Cambridge University Press, London, U.K.

Fuxa, J.R. and A.R. Richter (1992). Virulence and multi-generation passage of a nuclear polyhedrosis virus selected for an increased rate of vertical transmission. Bio. Cont., 2: 171-175.

Gelernter, W.D., N.C. Toscano, K. Kido and B.A. Federici (1986). Comparison of a nuclear polyhedrosis virus and chemical insecticides of the beet armyworm (Lepidoptera: Noctuidae) on head lettuce. J. Econ. Entomol., 79 : 714-717.

Grzywacz, D., K.A. Jones, G. Moawad and A. Cherry (1998). The in vivo production of Spodoptera littoralis nuclear polyhedrosis virus. J. Virological Methods, 71: 115-122.

Hughes, P.R. (1990). ViStat: statistical package for the analysis of baculovirus bioassay data: version 2.1. Boyce Thompson Inst. at Cornell Univ., Ithaca, USA.

Hughes, P.R., N.A.M. Vanbeek and H.A. Wood (1986). A modified droplet feeding method for rapid assay of Bacillus thuringiensis and baculoviruses in noctuid larvae. J. Invert. Pathol., 48: 187-192.

Jehle, J.A., G.W. Blissard, B.C. Bonning, J.S. Cory, E.A. Herniou, G.F. Rohrmann, D.A. Theilmann, S.M. Thiem and J.M. Vlak (2006). On the classification and nomenclature of baculoviruses: a proposal for revision. Arch. Virol., 151: 1257-1266.

Jones, K.A., N.S. Irving, D. Grzywacz, G.M. Moawad, A.H. Hussein and A. Fargahly (1994). Application rate trials with a nuclear polyhedrosis virus to control Spodoptera littoralis (Boisd.) on cotton in Egypt. Crop Prot., 13: 337-340.

Laarif, A., E. Salhi, S. Fattouch and M.H.B. Hammouda (2011). Molecular detection and biological characterization of a nucleopolyhedrovirus isolate (Tun-SINPV) from Spodoptera littoralis in Tunisian tomato greenhouses. Annal. Biol. Res., 2 : 180-191.
Martins, T., R. Montiel, J. Medeiros, L. Oliveira and N. Simes (2005). Occurrence and characterization of a nucleopolyhedrovirus from Spodoptera littoralis (Lepidoptera: Noctuidae) isolated in the azores. J. Invert. Pathol., 89 : 185-192.

McNitt, L., K.E. Espelie and L.K. Miller (1995). Assessing the safety of toxin-producing baculovirus biopesticides to a non-target predator, the social wasp Polistes metricus Say. Biol. Cont., 5: 267-278.

Moscardi, F. (1999). Assessment of the application of baculoviruses for the control of Lepidoptera. Ann. Rev. Entomol., 44: 257-289.

Moscardi, F. (2007). A nucleopolyhedrovirus for control of the velvetbean caterpillar in Brazilian soybeans. In Biological Control: A Global Perspective; Vincent, C., Goethel, M.S., Lazarovits, G., Eds.; CAB Int.: Oxford, UK, 344-352.

Moscardi, F., M. de Souza Lobo, M.E. de Castro Batista, L.M. Moscardi and B. Szewczyk (2011). Baculovirus pesticides: Present state and future perspectives. In Microbes and Microbial Technology; Ahmad, I., Ahmad, F., Pichtel, P., Eds.; Springer: New York, NY, USA, 415-445.

Pineda, S., M.S. Chneider, G. Smagghe, A. Martinez, P.D. Stal, E. Vinuela, J. Valle and F. Budia (2007). Lethal and sublethal effects of Methoxyfenozide and spinosad on Spodoptera littoralis (Lepidoptera: Noctuidae). J. Econ. Entomol., 100 : 773-780.

Sambrook, J., E.F. Fritsch and T. Maniatis (1989). Molecular Cloning: a Lab. Manual. Vol. 3. Cold Spring Harbor Laboratory Press, Cold Spring Harbor, New York, USA.

Smagghe, G., B. Carton, W. Wesemael, I. Ishaaya and L. Tirry (1999). Ecdysone agonists mechanism of action and application on Spodoptera species. Pestic. Sci., 55: 343389.

Theilmann, D.A., G.W. Blissard, B. Bonning, J.A. Jehle, D.R. O'Reilly, G.F. Rohrmann, S. Thiem and J.M. Vlak (2005). Baculoviridae. In: Fauquet, C.X., Mayo, M.A., Maniloff, J., Desselberger, U. and Ball, L.A. (Eds), Virus 
Taxonomy-Classification and Nomenclature of Viruses, 177-185. $8^{\text {th }}$ Report of the Int. Committee on the Taxonomy of Viruses. Elsevier, Amsterdam, Holland.

Topper, C.P., G. Moawad, D.J. McKinley, M. Hosny, K.A. Jones, S. El-Nagar and M. ElSheikh (1984). Field trials with a nuclear polyhedrosis virus against Spodoptera littoralis on cotton in Egypt. Trop. Pest Manag., 30: 372-378.
Toprak, U. and M.O. Gurkan (2004). First record of a NPV isolated from Spodoptera littoralis (Boisd.) (Lepidoptera: Noctuidae) in Turkey and its molecular identification according to the partial lef- 8 gene. Turk. J. Biol., 28 : 71-77.

Volkman, L.E., G.W. Blissard, P.D. Friesen, B.A. Keddie, R.D. Possee and D.A. Theilmann (1995). Baculoviridae. In Virus Taxonomy, (Murphy FA, Ed.), Springer Verlag, 104-113.

\title{
الفعالية والقدرة الإبادية للفيروس البوليهيدري النووي SpliNPV على تغذية وحساسية يرقات دودة ورق القطن الكبرى
}

\author{
لمياء السيد عبد الخالق ـ السيد عبد المالك الثيخ ـ ديدير أحمد راغب ـ محمد باسم علي عاشور

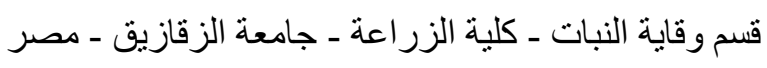

عُرفت الفيروسات العصوية الممرضة للحشرات بأنها بدائل آمنة بيئيا للمبيدات الكيميائية، تم دراسة القدرة الإبادية

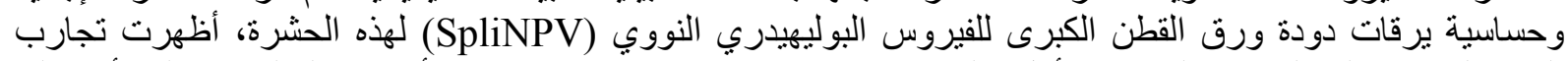

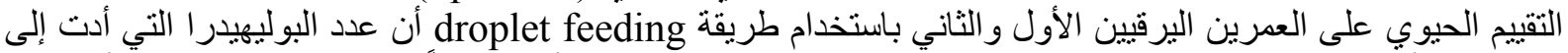

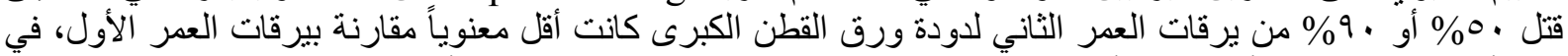

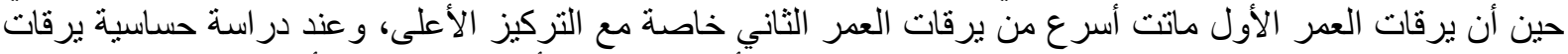

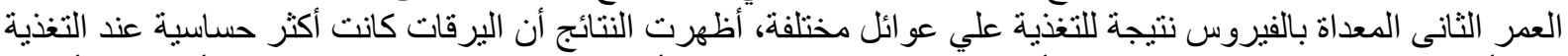

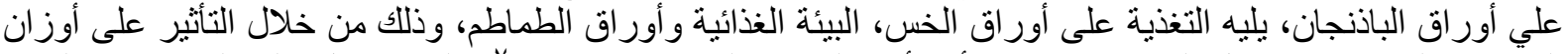

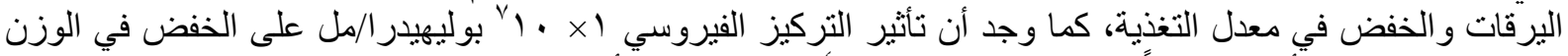

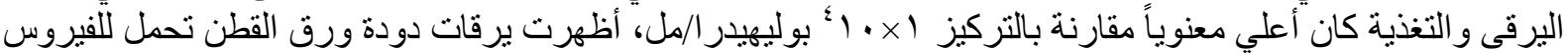
SpliNPV

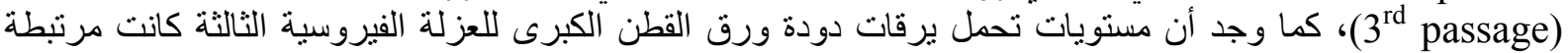

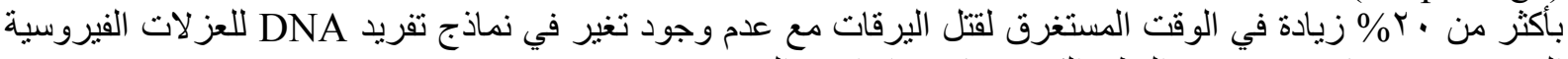

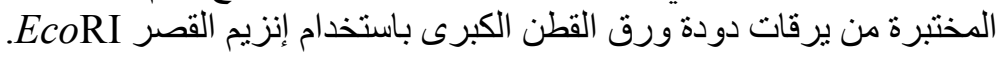

